Historic, Archive Document

Do not assume content reflects current

scientific knowledge, policies, or practices. 



\section{IMPORTED NOVELTY SEEDS}

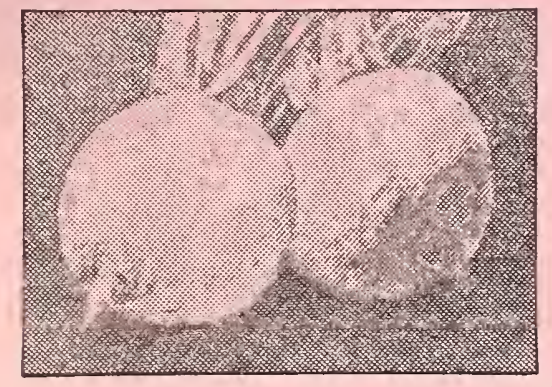

THE KOREAN TURNIP

This Turnip is a native of North Asia but it is a Vegetable that readily "beconies at home" in almost any climate. By planting at intervals it will crop all the year round. It is a small turnip, which makes it best for table use where the family is small as there are no pieces left to cook another day, or to be wasted, as is the case with the large ones. They are almost round with a smooth white skin. The flesh is tender and sweet, and they are so firm that they stand more 1 andling witlout spoiling than any other variety.

The seeds are Imported and absolutely Fresh,

Package of Seeds 25c.

\section{THE WO YDERFL MADAGASCAR BLAN}

A rery strong EVERGREEN PERENNIAL CLIMBER, producing immense quantities of large, flat, nutritious Beans, very much sought after in Australia, New Zealand and South Africa, not alone for the fruit it produces, but it makes an excellent climber for shutting out unsightly places.

The vines are so prolific it is estimated that in a moderately warm situation, and good soil, two plants will supply a small family for nine months in the year.

It is not necessary to have poles as the vines are natural climbers and will cling to old houses, $f$ nces, posts or trees. The beans are not only very nutritious but have a flavor and tenderness equal to any of the best varieties of their kind.

Pick when young and cook the same as the ordinary string bean. The seeds are slow to germinate unless put into hot water and allon $\mathrm{d}$ to soak for at least 12 hours.

The seeds are the genuine Black Seeded Madagassar Bean and not a "Jack B $\leq a n$ " or a mere flowering Vine. They are a Perennial, although un ter favorable conditions they may crop the season they are planted, but as a rule a perenuial will not crop until the following stason. Do nct pass judgment on the look of the seed or the vine, wait until you see and and try the Beans. The seeds are Imported by us and are Fresh.

\section{1 package containing 25 seeds $50 \mathrm{c}$.}

\section{THE DESERT PEA.}

\section{The Finest Native Flower of Australia.}

This beatiful plant is a Biennial Trailer, it is comparatively easy of cultivation, requiring a light sandy soil, well drained, and plenty of heat to bring out its flower's to their highest beauty. They are a brilliant searlet with intense black spots in the center.

Seeds should be planted where they are to remain as it will not easily transplant. The seeds require to be soaked in hot water before sowing. No new manure must be allowed to come in contact with the plants, but any old lime or building refuse will be beneficial.

Seeds $50 \mathrm{c}$ per package.

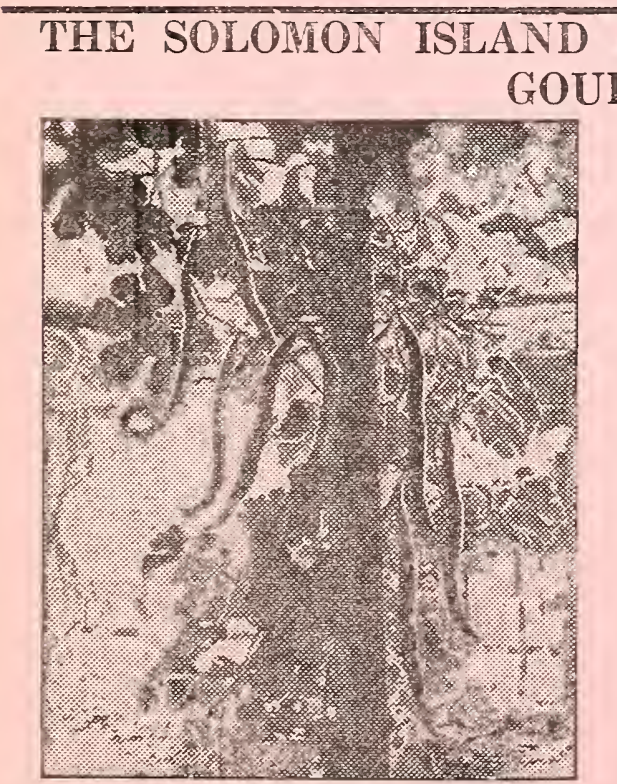
DDIBLE ORNAMENTAL OURD. length of 5 and 6 feet, they assume rarious shapes, some straight, some bent and coiled like large snakes ready to strike, their color is green with white stripes, but when over-ripe some will be yellow, some purple and others a deep copper red. They make a very rare and attractive appearance.

The "Cottage Gardener", (a leading Australian Garden Magazine) says: "It is the most appetizing Vegetable grown,-they are splendid, no peeling, no strings, no trouble.'

Complete Instructions regarding this Splendid Vegetable with every" package.

Seeds per package, 6 for $25 \mathrm{c}, 16$ for $50 \mathrm{c}$.

All seeds freshly gathered and are imported by us. Sent by mail to any address. Money Orders, Checks, Currency or Silver.

THE NOVELTY SEED IMPORTING CO., 121 Second Street, San Francisco, Calif. 


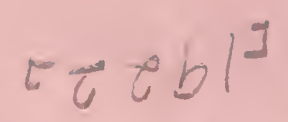

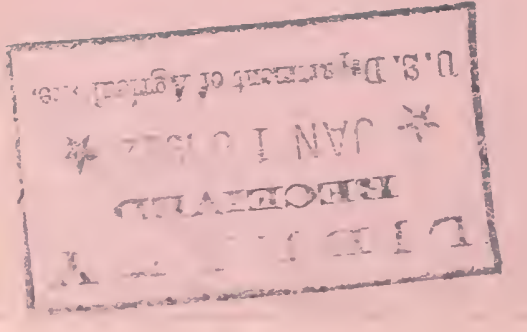

$30 \div 9$ 